\title{
ARBITRATION IN EU COMMISSION CLEARED MERGER TRANSACTIONS
}

\author{
Patrick Wautelet \\ Professor of Law, University of Liège \\ Attorney-at-Law, Brussels
}

I. WHERE TWO WORLDS MEET.

II. ARBITRATING POST-MERGER COMMITMENTS AND THIRD PARTIES.................. 4

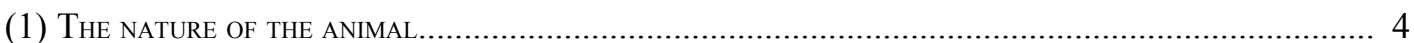

(2) SHOULD THE THIRD PARTY ACCEPT THE OFFER TO ARBITRATE?

III. ARBITRATION IN THE SHADOW OF THE MTF?....................................................... 8

IV. CONCLUDING OBSERVATIONS.......................................................................................... 11

\section{WHeRE TWO WORLDS MEet}

1 In the past, the worlds of (European) competition law and arbitration law have collided on numerous occasions. ${ }^{1}$ Suffice it to refer to the following issues to demonstrate the extent of this collision ${ }^{2}$ :

- can an arbitrator make a reference arbitrators for preliminary rulings to the ECJ to obtain some clarification on a disputed point of EU competition law ? $^{3}$

- can an arbitral award be challenged before national courts if it appears that the arbitrators have neglected to apply some EU competition rules ? (the infamous Eco-swiss case) ${ }^{4}$

- Can arbitrators determine whether an exemption under Article 81(3) would most likely have been granted by the Commission ? ${ }^{5}$

Both the competition and the arbitration worlds answer to their own logic. These examples of collisions have touched some raw nerves in the past. The confrontation may have fostered a better understanding of two separate worlds, which in the past did not always understand each other and each other's approach.

2 It had long been thought that, of all EU competition processes, merger regulation was immune from arbitration / or at least that arbitration could play no role in such clearing processes. This has changed dramatically over the last few years.

\footnotetext{
${ }^{1}$ See generally, W. Abdelgaward, L'arbitrage et droit de la concurrence, Paris, LGDJ, 2001.

${ }^{2}$ For recent accounts of the relationships between the two worlds, see H. LESGUILLons, "La solitude pondérée de l'arbitre face au droit de la concurrence", Cahiers de l'arbitrage in Gazette du Palais, mai 2003, 17-23 and L. Ірот, "Arbitration and the Reform of Regulation 17/62 », in European Competition Law Annual 2001 : Effective Private Enforcement of EC Antitrust Law, C.-D. Ehlermann, Hart, Oxford, 2003, 307-321.

${ }^{3}$ See the Nordsee ruling of the ECJ, 23 March 1982, case 102/81, E.C.R., 1982, 1095.

${ }^{4}$ See A. Mourre, «Les rapports de l'arbitrage et du droit communautaire après l'arrêt Eco Swiss de la CJCE ", Recueil des Cahiers de l'arbitrage, 77 ; R. von MEHREN, « The Eco-Swiss Case and International Arbitration », Arbitration Intl., 2003, 465-469; N. ShelkoplyAs, «European Community Law and International Arbitration : Logics that Clash » Eur. Business Organization L. Rev., 2002, 569-591.

${ }^{5}$ See e.g. ICC Arbitral award N 10246, discussed by E. JoLIVET, "Chronique de jurisprudence arbitrale de la Chambre de commerce internationale (CCl). Quelques exemples du traitement du droit communautaire dans l'arbitrage $\mathrm{CCl}$ », Cahiers de l'arbitrage in Gazette du Palais, mai 2003, (3), 7-8.
} 
Starting in 2000, the European Commission accepted, albeit reluctantly, to consider behavioural commitments made by merging entities. In the past, the Commission had considered that such commitments were not adequate to ensure competitive market structures. Following a decision of the Court of First Instance in the Gencor/Lonrho case, ${ }^{6}$ the Commission was forced to accept behavioural commitments next to structural commitments (such as divestments). ${ }^{7}$

Compliance with structural remedies can be monitored fairly easily by the Commission. Structural commitments entail mostly divestments needed to maintain an acceptable level of competition. Such divestments are required to be made within a short period of time. The Commission customarily appoints a trustee ('Monitoring Trustee' or 'Divestiture Trustee') to look after the commitments. ${ }^{8}$

Behavioural commitments, however, require more extensive monitoring, since they concern the future behaviour of the merged entity. A typical behavioural commitment would require the merged entity to continue supplies to a third party on a nondiscriminatory basis. Monitoring these commitments is time consuming and the Merger Task Force (MTF) does not have the necessary resources to do so - even though the MTF has recently created an 'enforcement unit'.

3 One of the solutions favoured by the MTF to monitor compliance with these new commitments, was to impose an arbitration agreement to the merged entity. Practice of Commission : arbitration is provided as a dispute resolution mechanism in the context of such behavioural commitments.

The first such reference to arbitration in a commitment, is to be found in a 1992 decision concerning Elf Aquitaine. ${ }^{9}$ Since 2000, references to arbitration have become more and more frequent.

The Südzucker case provides a typical example of this practice. This German company acquired sole control of a large French competitor, Saint Louis Sucre S.A. The merger gave rise to substantial concerns, since Südzucker was already one of the world's largest producer of sugar. The Commission concluded that the dominant position of Südzucker would be substantially strengthened and required commitments to restore competition.

Besides some divestments, Südzucker was required to undertake to sell to competing sugar manufacturers interested in making supplies to the Southern part of Germany, a quantity of up to 90.000 tons of sugar per year. To ensure compliance, Südzucker was required to conclude a framework agreement. Within that agreement, Südzucker committed to arbitrate any dispute which could arise with a third party competitor, particularly in respect of the pricing. The arbitration agreement read as follows :

\footnotetext{
${ }^{6} \mathrm{CFI}, 25$ March 1999, Gencor v. Commission [1999] ECR II-753, in particular § 319 : "The categorisation of a proposed commitment as behavioural or structural is therefore immaterial. It is true that commitments which are structural in nature, such as commitment to reduce the market share of the entity arising from a concentration by the sale of a subsidiary, are, as a rule, preferable from the point of view of the Regulation's objective, inasmuch as they prevent once and for all, or at least for some time, the emergence or strengthening of the dominant position previously identified by the Commission and do not, moreover, require medium or long-term monitoring measures. Nevertheless, the possibility cannot automatically be ruled out that commitments which prima facie are behavioural, for instance not to use a trademark for a certain period, or to make part of the production capacity of the entity arising from the concentration available to third-party competitors, or, more generally, to grant access to essential facilities on non-discriminatory terms, may themselves also be capable of preventing the emergence or strengthening of a dominant position".

${ }^{7}$ The Notice on Remedies Acceptable under Regulation EEC N ${ }^{\circ} 4064 / 89$.

${ }^{8}$ For more details, see MARC Blessing, Arbitrating Antitrust and Merger Control Issues, Helbing \& Lichtenhahn, 2003, $71 \mathrm{ff}$. and the Best Practice Guidelines for Divestiture Commitments, of 2 May 2003. ${ }^{9}$ Decision of the Commission Case N IV/M.235 of 4 September 1992, Elf Aquitaine - Thyssen / Minol.
} 
"Südzucker wird mit dem Händler einen Rahmenlieferungsvertrag abschliessen, der diesen berechtigtn eine Menge von bis zu 90.000 t pro Jahr u beziehen. In dem Rahmenlieferungsvertrag ist eine Scheidsklausel verzusehen, auf Grund derer der Händler im Streitfalll die vorherige oder nachträgliche Entscheidung eines Scheidsgerichts darüber herbeiführen kann, ob die von Südzucker über die Interventionspreis hinaus berechneten Kosten unter Beachtung der Ziffer 16 dieser Zusage gerechtfertigt sind. Südzucker wird den Händler nach einemn von diesem jährlich zum 15. September zu erstellenden Abrufplan beliefern, in dem die voraussichtlichen Mengen, Quälitaten Verpackungstypen und Lieferwerke aufgeführt sind". ${ }^{10}$

$4 \quad$ Since then arbitration agreements have been included to ensure compliance with commitments made, among other, in the airline industry, ${ }^{11}$ in the media industry, ${ }^{12}$ and in the spirits industry. ${ }^{13}$ Over the past few years, the practice of including an arbitration agreement in the commitment letter has rapidly grown. ${ }^{14}$ The new Merger Regulation ${ }^{15}$ does not touch upon the issue of arbitration as a resolution method for difficulties with behavioural commitments. It is widely expected, however, that the practice of insisting upon arbitration as a monitoring tool, will continue after the new Regulation comes into force on 1 May 2004.

5 Doubts have been raised concerning the legitimacy of entrusting private arbitrators with the power to assess whether a merged entity complies with the commitments imposed by the Commission. Ms. Idot has expressed doubts as to the existence of a legal basis under European law for such a 'delegation of powers' by the Commission. ${ }^{16}$

This question seems rhetorical at best. Ms Idot does not actually insist on this argument. ${ }^{17}$ Suffice it to say that, at this moment, the practice is sufficiently well established that it deserves to be investigated, even if questions could be asked regarding its legal basis. ${ }^{18}$

In this paper, we will look first at the effect this new practice may have on the position of third parties competitor (II) before examining the exact nature of this new field of application for commercial arbitration (III).

\footnotetext{
${ }^{10}$ Appendix II to Decision of 10 December 2001, Case $N^{\circ}$ Comp./M. 2389, O.J.C.E., C-211 of 28 July 2001, 53.

${ }^{11}$ See Decision of 27 November 1992 in the matter of British Airways / TAT, case N ${ }^{\circ}$ IV/M.259, O.J.E.C., 11 December 1992, C-326 and Decision of 20 July 1995 in the matter of Swissair / Sabena II, Case N ${ }^{\circ}$ IV/M.616, O.J.E.C., 4 August 1995, C-200/10.

${ }^{12}$ See Decision of 21 March 2000 in the matter of BskyB / Kirch PayTV, Case N ${ }^{\circ}$ Comp./JV.37, O.J.E.C., 15 April 2000, C-110/45 and Decision of 13 October 2000 in the matter of Vivendi / Canal + / Seagram, case $\mathrm{N}^{\circ}$ Comp./M.2050, O.J.E.C., 31 December 2000, C-311/3.

${ }^{13}$ See Decision of 8 May 2001 in the mater of Pernod Ricard / Diageo / Seagram Spirits, Case $N^{\circ}$ Comp./M.2268, O.J.E.C., 19 January 2002, C-16/13 and Decision of 15 October 1997 in the matter of Guinness / Grand Metropolitan, Case N IV/M.938, O.J.E.C., 27 October 1998, L-288/24.

${ }^{14}$ See for an overview of the different cases, $C_{H}$. LIEBSCHER, "L'arbitrage dans les procédures de contrôle des concentrations : des perspectives », Cahiers de l'arbitrage in Gazette du Palais, mai 2003, 24-39.

${ }^{15}$ Regulation $139 / 2004$ on the control of concentrations, adopted by the European Council on 20 January 2004 (published in the Official Journal of 29 January 2004, L-24/1).

${ }^{16} \mathrm{~L}$. IDOT, “Une innovation surprenante : l'introduction de l'arbitrage dans le contrôle communautaire des concentrations », Revue de l'arbitrage, 2000, (591), 598.

${ }^{17} \mathrm{Mr}$. Lesguillons writes that arbitration of merger commitments "does not raise ontological problems" (H. Lesguilzons, art. cit., Cahiers de l'arbitrage in Gazette du Palais, mai 2003, 17).

${ }^{18} \mathrm{Mr}$. Liebscher convincingly argues that the practice of the Commission raises no issue of principle since the Commission does not delegate the jurisdiction to review the merger as such; the arbitration panel is only entitled to examine compliance with the commitments made to obtain clearance of the merger : С H. LIEBSCHER, art. cit., Gazette du Palais, mai 2003, 38-39.
} 


\section{Arbitrating post-Merger commitments and thiRd parties}

6 The practice of the Commission to impose arbitration as the dispute resolution method for commitments disputes raises new opportunities for third party competitors who may experience the drawbacks of a merger.

Before reviewing the merits and pitfalls of this new avenue (2), one should reflect on the very nature of the dispute resolution mechanism imposed by the MTF (1).

\section{(1) The nature of the animal}

7 The first question that comes to mind when reviewing the dispute resolution agreements imposed by the MTF as part of post-merger commitments, is to what extent the MTF indeed imposed arbitration as a monitoring tool.

In some instances, there is no doubt the MTF required the merged entity to submit to what appears to be 'classic' arbitration. The arbitration can be ad hoc (as in the Carrefour/Promodès ${ }^{19}$ and the Danish Crown decisions ${ }^{20}$ ). In several instances, the Commission has accepted that disputes should be submitted to institutional arbitration (LCIA or ICC, see the Vivendi decision ${ }^{21}$ - ICC - and the Guinness/Grand Metropolitan decision ${ }^{22}$ - LCIA). This suggests that the MTF will not impose any particular form of arbitration, or favour one arbitral institution above another, but will simply take what the merged entity offers, provided other requirements are met, and in particular the swiftness of the resolution (see infra). Hence, there seems to be room for the counsels of the merged entity to insist on a particular form of arbitration, if the company is more at ease with one institution or another.

In other instances, reference was made to a more sophisticated dispute resolution mechanism. In the Vodafone decision, the merged entity submitted undertakings aimed at enabling third parties non-discriminatory access to the merged entity's integrated networks so as to provide advanced mobile services to their customers. To that end, Vodafone Airtouch suggested to set up a so-called Fast Track Dispute Resolution Procedure in order to solve disagreements between the merged entity and the third parties. ${ }^{23}$ This procedure essentially consists in an obligation imposed on Vodafone to provide detailed written reasons for the decision that has been challenged by the third party. The commitment also provides for the detailed reasoning to be appreciated by an arbitral tribunal whose proceedings will be conducted in accordance with the rules of the LCIA. This type of agreement, which is further accompanied by a wealth of details, certainly deviates from the traditional arbitration. It may, as has been observed, that a 'normal' arbitration would not adequately deal with the specific issues that may arise following this type of merger. ${ }^{24}$

\footnotetext{
${ }^{19}$ Decision of 25 January 2000, Carrefour / Promodès, Case $N^{\circ}$ Comp./M. 1684, O.J.E.C., 14 June 2000, C-64/5. The undertaking reads as follows : "Carrefour s'engage à proposer à tous les fournisseurs [...] de soumettre les litiges qui porteraient sur l'interprétation, l'application ou l'exécution des engagements de Carrefour, à un arbitre unique désigné d'un commun accord par les parties, étant entendu que l'arbitre sera un expert indépendant ».

${ }^{20}$ Decision of 9 March 1999, Danish Crown / Vesjyske Slagterier, Case N IV/M.1313, O.J.E.C., 25 January 2000, C-20/1.

${ }^{21}$ Decision of 13 October 2000, Vivendi / Canal + / Seagram, Case N Comp./M.2050, O.J.E.C., 31 December 2000, C-311/3.

${ }^{22}$ Decision of 15 October 1997, Guinness / Grand Metropolitan, Case N IV/M.938, O.J.E.C., 27 October 1998, L-288/24.

${ }^{23}$ Decision of 12 April 2000, Vodafone Airtouch / Mannesman, Case N Comp./M.1795, O.J.E.C., 19 May 2000, C-141/19.

${ }^{24}$ As has been observed by MARc Blessing, Arbitrating Antitrust and Merger Control Issues, Helbing \& Lichtenhahn, 2003, 109.
} 
The Shell / BASF / J V Nicole decision provided for a commitment in favour of third parties active in the resin business : the merged entity agreed to license its patent rights on a non-discriminating, arm's length basis to all interested parties, with the right for such licensees to grant sub-licenses..$^{25}$ This commitment was submitted to what may be called 'pendulum arbitration', whereby the parties agreed to submit a single proposal to the arbitration tribunal, which was required to decide in favour of one of these two proposals in its entirety.

In yet other instances, the dispute resolution mechanism imposed by the Commission is more difficult to characterize. In the Elf Aquitaine case, the Commission indeed imposed "arbitration by mutually agreed independent experts". ${ }^{26}$ This is a rather hybrid formula, with gives rise to the risk that the parties first dispute the nature of the animal. ${ }^{27}$

This suggests that the Commission is not as such concerned by the classic distinction between expert decision and 'real' arbitration. The MTF is apparently interested in the efficiency of the dispute resolution method and not by the delicate distinctions made in the literature between the various types of alternative dispute resolution methods.

8 More generally, one can wonder whether the mechanism contemplated by the MTF really fits the classic definition of arbitration as a contractual dispute resolution method, i.e. a method agreed upon between two, or more, parties. The contract forms the basis, and at the same time, the limitation of the arbitral tribunal's jurisdiction.

With this in mind, can one still pretend that the arbitration clause found in some commitment letters constitutes a real agreement to arbitrate? In most cases, there will not be any agreement between the merged entity and the competitor. Take the example of the Südzucker case : a dispute will precisely arise when Südzucker and a competitor do not agree on the price to be charged, or other conditions, for the sugar. Can such a dispute be referred to arbitration?

This does not actually raise difficulties. It is true that there may not be any contract between the merged entity and the third party, unlike in the classic arbitration situation. However, the arbitration clause to be found in the commitment letter constitutes a unilateral offer to arbitrate, an offer that is made erga omnes, or at least to all competitors concerned, to accept arbitration to resolve a particular dispute.

If the third party initiates the procedure and takes up the offer to arbitrate a dispute, the consent of both parties to arbitrate will be manifest. The arbitrators could take the opportunity to record this consent in terms of reference, in order to avoid any later dispute on their jurisdiction.

\footnotetext{
${ }^{25}$ Decision of 29 March 2000, Shell / BASF / JV Project Nicole, Case N Comp./M.1795, O.J.E.C., 20 May 2000, C 142/35. The clause reads as follows : "If no agreement can be reached on the consideration for a License or Non-Assert, such disagreement will be resolved by 'pendulum arbitration'. Pursuant to such arbitration, each party will submit a single proposal for the consideration for such License or Non-Assert to the arbitration panel which can only decide in favour of one of the two submittted proposals in its entirety."

${ }^{26}$ Decision of the Commission Case N ${ }^{\circ}$ IV/M.235 of 4 September 1992, Elf Aquitaine - Thyssen / Minol : the Decision reads as follows : "Arbitration by mutually agreed independent experts will be provided in cases of disputes relating to the application of the agreement".

${ }^{27}$ This is further illustrated by the fact that some agreements provide for ICC or LCIA arbitration and at the same time provide for a default appointment of the presiding arbitrator by a local judge. See Decision of 8 May 2000 in the matter of Glaxo Wellcome / Smithkline Beecham, case N Comp./M.1846, O.J.E.C., 20 June 2000, C-170/6, which provides that "Any dispute arising under or in connection with [this undertaking] shall be determined by arbitration in London pursuant to the rules of the London Court of International Arbitration by a single arbitrator chosen by agreement between the parties, failing which the arbitrator shall be chosen by the President of the Law Society of England and Wales". Obviously, the jurisdiction given to the President of the Law Society cannot be reconciled with the rules of the LCIA... See in particular Article 5-5 of the LCIA rules.
} 
This is simply a new manifestation of what has been called "arbitration without privity". ${ }^{28}$ The arbitration provision included in most bilateral investment treaties allows investors to submit disputes with the host State to arbitration even though these two parties may not have signed a contract. ${ }^{29}$ Likewise, there may not be a contract between the merged entity and the third party, but provided the latter accepts the offer made by the former, in the commitment letter, to arbitrate eventual disputes, the arbitration has a sufficient contractual basis.

\section{(2) Should the third party accept the offer to arbitrate?}

$9 \quad$ Once it has been accepted that the commitment by the merged entity merely constitutes an offer to arbitrate a dispute, consideration should be given to the question whether the third party competitor should accept this offer.

It is obvious the third party is not required to arbitrate eventual disputes with the merged entity. ${ }^{30}$ This is merely a possibility offered by the commitment letter. This begs the question whether the third party should take up the offer made by the merged entity.

It is not possible to offer a general answer to this question. Given the differences existing between each merger, businesses deserve a tailored made answer. However, a few pointers can be provided on the advantages offered by arbitration.

There are, indeed, strong arguments to favour arbitration as offered in the commitments to resolve disputes with the merged entity - besides the usual advantages of arbitration over litigation in state court.

10 First of all, arbitration certainly offers a neutral venue to settle the dispute. In most cases, parties will not (yet) be bound by a contract. This means disputes may have to be brought before the home courts of the merged entity. It may indeed not always be possible to attract the merged entity before the competitor's local courts.

Against this background, arbitration may offer a better alternative. At least, the arbitration tribunal will provide a more neutral venue than the courts of the merged entity. In that respect, it is interesting to note that not all arbitration agreements define the seat of the arbitration tribunal. Even though most experienced arbitrators will argue that an arbitration clause which does not define the seat of the arbitration, is flawed, it is remarkable to note that the arbitration agreements found in commitment letters only rarely include details on this issue. ${ }^{31}$ It is to be hoped that future arbitration agreements will take care of this issue. ${ }^{32}$

Could the arbitration commitment locate the seat of the arbitral tribunal outside the European Union? On could think for example of Switzerland. It is doubtful whether the MTF will agree to this. If the seat of the tribunal is located outside the EU, this would mean that the national court exercising primary control over the award, would not directly be bound by European law, and in particular by the Commission's decision on the

\footnotetext{
${ }^{28}$ To use a phrase coined by J. PAULSSON, « Arbitration Without Privity », ICSID Review, 1995, Vol. 10/2, 232-257.

${ }^{29}$ See e.g. Article $8(3)$ of the Bilateral Investment Treaty between Belgium and Burundi signed on 13 April 1989 (Act of 19 April 1991, published in the Official Gazette of 16 September 1995).

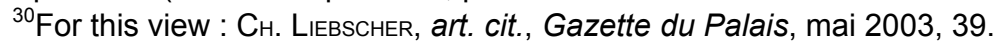

${ }^{31}$ In the Vivendi / Canal + / Seagram case, arbitration was to be held in London. The same was provided for in the Shell/DEA case. The Alcatel/Thomson decision chose for Paris (Decision of 4 June 1998 in the matter of Alcatel / Thomson CFS-SCS, Case N IV/M.1185, O.J.E.C., 1 Sept. 1998, C-22-5). The Dow Chemical / Union Carbide provided for arbitration in Amsterdam (Decision of 3 May 2000 in the matter of Dow Chemical / Union Carbide, Case N Comp./M.1671, O.J.E.C., 14 Sept. 2001, C-245/1).

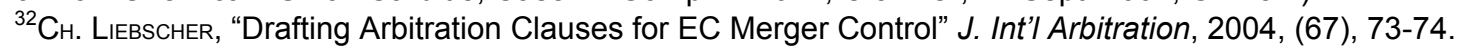


merger. The award could therefore not be challenged on the ground that the arbitrators ignored one or the other provisions of European law. ${ }^{33}$ Hence, it seems better to provide that the arbitral tribunal will have its seat in one of the Member States.

11 The competitor will also benefit from some of the features that are most probably included in the arbitration agreement at the Commission's express request. The Commission indeed ensures that the arbitration agreement be drafted in a fairly balanced way.

The first feature of the arbitration that could prove favourable to the competitor's interests, is the tight time frame on which the Commission insists. The MTF apparently is very keen to ensure that possible disputes be settled very fast. Severe time limits are imposed for the arbitrators to conclude their mission and render an award.

In the Alcatel/Thomson decision, the Commission imposed a fast track arbitration : the arbitrator was required to pronounce the award within two months. ${ }^{34}$ In other decisions, the Commission even required a decision within a time period of one month. ${ }^{35}$

It can be asked whether these time frames are realistic, given the nature of the arbitral process and the need to respect the due process. ${ }^{36}$ In any case, the requirements imposed by the Commission ensure that the third party competitor will obtain a decision within a very reasonable period of time, and often much sooner than if proceedings were brought before a state court. It may also be noted that the time frame imposed by the Commission will influence the choice of arbitrators : any potential arbitrator must indeed have plenty of time available in a very short period to handle the arbitration.

12 It is not common to find rules on the burden of proof in arbitration agreements. At most, this issue may be touched upon in terms of reference, if any such terms are drafted.

Some arbitration commitments found in post-merger cases depart from that finding. In some instances, the MTF indeed seems to have required that the arbitration commitment includes a precise regulation of the burden of proof of each parties. As included in some arbitration agreements, this regulation could ease the task of the third party competitor and could certainly prove very beneficial for third party competitors. In the Telia / Sonera case ${ }^{37}$ a case concerning the acquisition by Telia, a Swedish telecommunications and cable TV operator, of Sonera, active in the mobile telephone business in Finland, the Commission wanted to curtail Telia's possibility to leverage its strong position in the mobile telecommunications services market. To that end, the Commission imposed a non-discrimination obligation on Telia, for access by third party operators (and competitor) to Telia's network. Disputes relating to this obligation were to be submitted to a fast track dispute resolution procedure that was spelled out in great details in the Decision. ${ }^{38}$

\footnotetext{
${ }^{33}$ See on this issue CH. LieBsCHER, art.cit., J. Int'l Arbitration, 2004, (67), 74.

${ }^{34}$ Case IV/M.1185, § 38 of the Decision.

${ }^{35}$ Decision of 20 December 2001 in the matter of Shell/DEA, Case $N^{\circ}$ Comp./M.2389, O.J.E.C., 21 January 2003, C-276/31 : the arbitration clause required the arbitrators to render their decision "within one month of the appointment of the president of the arbitral tribunal". In the Vodafone Airtouch / Mannesmann, the decision provided that "the arbitral tribunal shall render its decision within one month after nomination" (Case Comp/M.1795). In the Telia / Sonera case, the decision provided that "the arbitrators shall make a decision within one month of the appointment of the third arbitrator" (Case Comp/M.2803, § 26 of the Annex).

${ }^{36}$ Marc Blessing (Arbitrating Antitrust and Merger Control Issues, Helbing \& Lichtenhahn, 2003, 170-171) writes that : "we fear that the European Commission does not always have a realistic view on the requirements of procedure and the requirements of due process in arbitral proceedings".

${ }^{37}$ Decision of 10 July 2002 in the matter of Telia / Sonera, Case N Comp./M.2803, O.J.E.C., 24 August 2002, C-201/19.

${ }^{38}$ Paragraphs 119,146 and 143 et seq. of the Decision. See also Paragraphs 26 et seq of the Annex.
} 
Interestingly for competitors, the Decision provided that :

"The burden of proof in any dispute under the Fast Track Procedure set out in this Clause is as follows : (i) the requesting party must produce evidence of a prima facie case, and (ii) if the requesting party produces evidence of a prima facie case, the arbitrator must find in favour of the requesting party, unless Telia, having had an opportunity to comment on evidence so produced, can produce evidence to the contrary".

Similar 'prima facie rules' can be found in other cases. ${ }^{39}$

Needless to say, such a rule greatly facilitates the task of the competitor and will make arbitration under the terms of the commitment an attractive alternative to proceedings before state courts. It will essentially be for the merged entity to discharge the burden of proof. As has been argued, there is some logic in imposing the burden of proof on the merged entity, since this entity will have privileged access to the relevant material and data. ${ }^{40}$ Nonetheless, this strikes as an unusually harsh position for the merged entity. It may even imperil the enforceability of an award. It is indeed not excluded that a national court finds that the merged entity has not had its day in court, since it had to discharge such a heavy burden of proof.

13 To sum up, it appears that, at least in most cases, the third party competitor will have strong reasons to take up the offer of the merged entity to arbitrate disputes. As fashioned by the MTF's requirements, arbitration indeed offers significant advantages that cannot be replicated by state courts. It is not excluded, however, to find cases where a third party may have specific reasons to seize such courts. One may think of the need to obtain urgent provisional measures. Some arbitration agreements have provided for the possibility for the arbitrators to hear claim for provisional measures. ${ }^{41}$ However, in most cases this issue has not been touched upon. Even if a party calls upon a state court to order some provisional measures, this will, however, not exclude to possibility to seize the arbitrators of the merits of the dispute.

\section{Arbitration in the shadow of the MTF?}

14 It has been shown that third party competitors have, on average, an interest in initiating arbitration proceedings as offered by the commitment letter.

What can they expect from the arbitration process? It is likely that the arbitration process will differ significantly from the traditional pattern familiar to those dealing with international commercial disputes.

This is due to the fact that the arbitrator carries out, in a first stage at least, a quasiregulatory function in determining whether or not the commitments made by the merged entity have been honoured. The arbitrator is indeed required to scrutinize the fulfilment

\footnotetext{
${ }^{39}$ The Vodafone/Mannesman decision, in the Shell/ DEA case, and in the Vivendi case (where the clause read as follows: "The burden of proof in any dispute under this Undertaking shall be as follows: (i) the complaining party must produce evidence of a prima facie case, and (ii) if the complaining party produces evidences of a prima facie case, the arbitrator must find in favour of the complaining party unless Universal can produce evidence to the contrary").

${ }^{40}$ Marc Blessing, Arbitrating Antitrust and Merger Control Issues, Helbing \& Lichtenhahn, 2003, 175. See

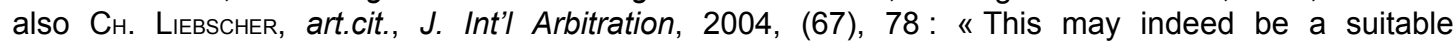
mechanism to balance a disequilibium as regards access to information ".

${ }^{41}$ See the decisions in the cases of Dow Chemical / Union Carbide; Shell / BASF and Alcatel / Thomson.
} 
and adherence of a party to the commitments endorsed vis-à-vis the European Commission.

In this respect, it may be said that the arbitrator works as the 'prolonged arm and instrument' of the EU Commission. His mission is not only to settle a dispute between private parties, but also to further the policy objectives set out in the Commission's decision. As such, this departs from the traditional adjudicatory function of arbitrators.

This has consequence on the nature of the arbitration process. Take for instance the classic issue of the law applicable to the merits of the dispute. This question usually needs to be addressed by the arbitral tribunal at an early stage of the process - unless the arbitrators rule as amiables compositeurs.

When arbitrating a dispute relating to a post-merger commitment, the issue of the applicable law loses much of its importance. The terms of the commitment are indeed self-explanatory and quasi self-executory. In most case, they will spell out with great precision what is expected from the merged entity. Compliance with these commitments is a fact-driven exercise, where there is less need to resort to legal rules.

Further, the particular nature of the arbitral process will certainly influence the selection of the arbitrators. Competition law issues tend to concern highly complex factual situations, with a heavy dose of economic reasoning. It is obvious that settling disputes of this kind requires specific expertise in the field of competition law. Further, as already underlined, the Commission insists on a swift decision by the arbitrators, and impose very tight time limits. This means that the arbitrator must have plenty of time available in a very short period to handle the arbitration. ${ }^{42}$

15 It is true that, in a second stage, the arbitrators may be called upon to focus on the consequences of a possible non compliance by the merged entity with the commitment. The arbitral tribunal may find it necessary to award damages. In doing so, the arbitrators will recover their ordinary adjudicatory function, i.e. settle a dispute between parties. The normal features of such adjudicatory process will apply, such as the need to determine the applicable law, e.g. to assess the eventual damages.

16 It is clear that the arbitration of post-merger commitments has a dual nature : regulatory in a first stage, it may recover its usual function in a second stage.

This raises the question of the exact nature of the arbitration contemplated by the Commission. It has been said that this type of arbitration was 'sui generis'. This characterization does not help to clarify the mission of the arbitrator.

In reality, it seems that the arbitrators will work, during the first stage of the proceedings, under close scrutiny, if not control, of the Commission. The Commission indeed usually reserves the right to influence the proceedings, or at least to be kept informed of the proceedings.

In some arbitration agreements, the MTF had required the merged entity to keep it informed of the existence of a dispute and the start of an arbitration proceedings. In other instances, the influence of the Commission will concern the nature of the procedure to be followed. In the BskyB case, the Commission reserved the right to impose the arbitration rules if the parties could not agree on the arbitration process. Other arbitration

\footnotetext{
${ }^{42}$ It seems that the ICC Task Force on Arbitrating Competition Issues (headed by Marc Blessing) will consider drafting a list of arbitrators with specific expertise in the field of antitrust arbitration. It may be noted that the merged entity may find it convenient to appoint the same person every time it is confronted with a dispute. This could prove a beneficial strategy.
} 
agreements gave the Commission a role in the appointment of the arbitrators. Usually, the Commission is granted the right to confirm the arbitrators. ${ }^{43}$

Even though this has not (yet) been expressly provided for in the arbitration agreements, one may imagine that the Commission will, at some stage, want to intervene directly in the arbitration proceedings. The MTF could file a request to be heard, or at least to file an amicus curiae brief, if it finds that this is required. It would be up to the arbitrators to appreciate such a request. One would have to find very good reasons to refuse such a request. In fact, the assistance of the Commission may be needed. Arbitrating disputes relating to post-merger commitments require broad investigation powers, to uncover the facts and all relevant materials. These powers may be available to the investigative agencies, but will not as such be available to an arbitral tribunal. This explains the peculiar rules relating to the burden of proof, to be found in some arbitration agreements. Absent such rules, the arbitrators may require the assistance of the Commission to carry out their the fact-finding mission. ${ }^{44}$

17 Given the peculiar nature of the arbitration contemplated by the MTF, one may ask whether the influence of the MTF will also extend to the outcome of the dispute. It is clear that the MTF will receive a copy of the award. ${ }^{45}$

Will the MTF take a second look at the award? What will happen if the MTF disagrees with the findings of the arbitrators? The arbitrators are naturally bound by the Commission's decision on the merger when determining whether a commitment has been breached. The Commission's decision provides the yardstick for the resolution of the dispute. It seems that, since the arbitrator carries out a quasi-regulatory function, he cannot ignore or side-step the Commission's decision. This will help avoid major differences of opinion between the MTF and the arbitrators.

It is not excluded, however, that the arbitrators come to findings that are not compatible with the MTF's view of the merged entity's behaviour. There will be no difficulty if the arbitrators have found in favour of the third party competitor, although the MTF was of the opinion that the merged entity's behaviour was in conformity with the commitments made. In that case, the competition will indeed not suffer. The situation could be more delicate if the arbitrators find in favour of the merged entity. The MTF could be of the opinion that the merged entity has violated its commitments.

Will the Commission retain the last word on the issues of compliance with the commitments? This would reduce the arbitrators to mere advisors of the MTF, without real adjudicatory power. There can be no doubt that a full review by the MTF of any award would be incompatible with the fundamental tenet of arbitration and in particular with the jurisdictional nature of arbitration. If the MTF insists on arbitration as a monitoring tool for compliance with commitments, it cannot reserve a right of review or confirmation of the award. Any other solution would degrade the arbitration to a mere administrative review process outsourced to a third party.

This is not to say that the Commission cannot intervene by other means. One could imagine that, in the most extreme case, the Commission would reserve the possibility to challenge the award before national courts. As the EC has held, "[a] national court to

\footnotetext{
${ }^{43}$ See the observation of $\mathrm{CH}_{\text {}}$. Liebscher, art.cit., J. Int'l Arbitration, 2004, (67), 80 : "As regards the selection of arbitrators, it seems doubtful that the Commission will have the necessary knowledge to judge a person's relevant track record and experience".

${ }^{44}$ Alternatively, the arbitrators may wish to appoint an expert, for instance an economist, for the purpose of ascertaining and evaluating the facts. See generally A. P. Komninos, "Assistance to Arbitral Tribunals in the Appliaction of EC Competition Law", in in European Competition Law Annual 2001 : Effective Private Enforcement of EC Antitrust Law, C.-D. EhLERMAnN, Hart, Oxford, 2003, 364-385.


has not taken a final position regarding the influence it wishes to exercise as to the arbitration procedure"
} 
which an application is made for annulment of an arbitration award must grant that application if it considers that the award in question is in fact contrary to Article 85 of the Treaty, where its domestic rules of procedure require it to grant an application for annulment founded on failure to observe national rules of public policy" ${ }^{46}$ This type of control seems sufficient to prevent the most egregious mistakes. ${ }^{47}$ There is thus no need to provide for a special review mechanism, in the arbitration agreement, under which the MTF would act as the 'step-mother' of the arbitrators.

\section{Concluding observations}

18 The practice of the MTF to impose arbitration as a monitoring tool to ensure and review compliance with post-merger commitments opens a new field for the world of commercial arbitration. Lawyers will be required to intervene first when drafting the arbitration 'agreement' in the negotiation phase with the MTF and further when advising client on whether or not to start arbitration proceedings if it appears that one or the other commitment has been breached. ${ }^{48}$

The preceding overview has shown that the 'arbitration' agreements included in commitment letters often include pathological aspects, which raise the risk of blocking the arbitration altogether. ${ }^{49}$ This should not come as a surprise, given that arbitration agreements are often drafted at a very late stage, when negotiations reach a final climax..$^{50}$ This also goes to show that the MTF does not (yet) possess sufficient expertise in arbitration and other dispute resolution methods, to master the fine art of drafting dispute resolution clauses. This will change in the future, as the MTF acquires the required expertise. Several initiatives will help in this process, such as e.g. the model arbitration agreement suggested by Marc Blessing. ${ }^{51}$

These and other issues will be discussed by specialized fora, where specialists from both the arbitration and the competition worlds will meet to work out their differences. ${ }^{52}$

It remains to be seen whether the abstract and general commitments to arbitrate included in some letters of commitment, will give rise to actual disputes being arbitrated. Unfortunately, the Commission does not seem to publish eventual findings on the application of the commitments.

\footnotetext{
${ }^{46}$ ECJ, Case C-126/97, Eco-Swiss China Time Ltd. v. Benetton International NV, [1999] ECR I-3055, para 41.

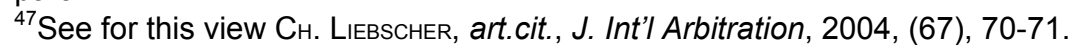

${ }^{48}$ Arbitration and related dispute resolution methods can also play other roles in the processes of mergers and acquisitions, see e.g. A. Sessler and C. Leimert, "The Role of Expert Determination in Mergers and Acquisitions under German Law", Arbitration international, 2004, 151-165.

${ }^{49}$ One example of such 'pathological' aspects of the arbitration clauses is to be found in the fact that, although almost all arbitration agreements provide for a very tight deadline for rendering the award, none of the agreements deal with the situation where the award is not rendered within this period of time; what happens if the arbitrator is not able to render his decision within the prescribed time period. Should he be considered functus officio?

${ }^{50}$ On this see the observations of L. IDOT, art. cit., Revue de l'arbitrage, 2000, (591), 599 : « [...] la rédaction de ces engagements parfois arrachés à la dernière minute, juste avant l'expiration des délais fatidiques [...] » and Marc Blessing, who writes about the "last minute creations of some of the rather exotic provisions [...] which, manifestly, had been devised under great time pressure and without careful thinking as to their suitability and workability" (MARC BLESSInG, Arbitrating Antitrust and Merger Control Issues, Helbing \& Lichtenhahn, 2003, 169).

${ }^{51}$ Draft Model Commitment Submitted to the Commission for Arbitrating Behavioural Undertakings, reproduced in Marc Blessing, Arbitrating Antitrust and Merger Control Issues, Helbing \& Lichtenhahn, 2003, 186.

${ }^{52}$ Both the ICC (the ICC Taskforce on Arbitrating Competition Law Issues, chaired by Marc Blessing) and the IAI have set up working groups to study these issues.
} 